\title{
Application of House of Risk (Hor) Models for Risk Mitigation of Procurement in The Balikpapan Samarinda Toll Road Project
}

\author{
Doddy Arief Wibowo ${ }^{1}$ and Ervina Ahyudanari ${ }^{2}$ \\ ${ }^{1}$ Department of Technology Management, Institut Teknologi Sepuluh Nopember, Surabaya \\ ${ }^{2}$ Department of Civil Enginnering, Institut Teknologi Sepuluh Nopember, Surabaya \\ e-mail: doddy_08@yahoo.com
}

\begin{abstract}
Abstrak-The Balikpapan Samarinda Toll Road Project built $99 \mathrm{~km}$ has a relatively short implementation time of 3 years. The accuracy of project completion is closely related to the procurement of materials during the implementation period. Risk analysis based on ISO 31000: 2009 where the risk of delay in procurement of materials is included in the extreme category with a high level of probability and severe impact. Risk analysis is carried out qualitatively, that is, determining risk priorities by determining the likelihood of events and their effects on project performance. Material procurement delays still occur due to various factors that have not been mitigated in the planned risk analysis. This resulted in project performance not on schedule. The purpose of this study is to provide a proactive framework for managing material procurement risks. The method used is the House of Risk (HOR) from the literature study. The HOR method is very commonly used in supply chain risk management. The HOR method focuses on preventive actions determining the main risk agents and the priority of preventive actions. The advantages of this method are in the framework that can cover the whole process of risk management. Phase 1 of HOR begins with the identification of risk events and phase 2 of risk treatment. This framework allows management to select priority risk agents to be mitigated and prioritize proactive actions to reduce the impact of risk events. The results of the study are 14 risk events and 15 risk agents that can occur in the material procurement process. From the Paretto Diagram, 4 risk agents were selected, namely schedule changes became faster, bill payments required a long period of time, problems in supplier selection, and material fabrication time. Based on the analysis of preventive action 3 actions proposed in this study are coordinating with the finance department to monitor supplier bills, coordinate with production for proper procurement schedules, and evaluate suppliers.
\end{abstract}

Keywords-Risk Management, House of Risk (HOR), Risk Mitigation, Material Procurement.

\section{INTRODUCTION}

$\mathrm{I}^{\mathrm{N}}$ $\mathrm{N}$ line with economic growth in East Kalimantan, the Government responded with the implementation of the Balikpapan - Samarinda Toll Road Construction, which became the first toll road in Kalimantan. The Balikpapan Samarinda toll road project is a national strategic project that connects the cities of Balikpapan and Samarinda along 99 kilometers. The project is divided into 5 segments and carried out multiyear for 3 years. The accuracy in the completion of the project is closely related to the accuracy of material procurement during project implementation. Project material procurement is a challenge that has a high risk so it needs to be controlled properly according to a predetermined procurement schedule. So that this becomes the author's background in conducting a risk analysis regarding the procurement of materials in toll road projects Balikpapan Samarinda to do the appropriate mitigation measures.

PT Wijaya Karya has established a Risk Management System policy using a framework that implements ISO 31000: 2009. The application of risk management systems at PT Wijaya Karya uses qualitative risk analysis, a method of determining priorities against risks using opportunity events and their effects on project performance. This study complements the analysis of original material procurement risk has been carried out using the method ISO 31000: 2009. The author uses another approach is the method of House of Risk (HOR) which is different from the method based on ISO 31000 .

The House of Risk (HOR) model is a framework developed by Geraldin and Pujawan (2009) by developing the FMEA (Failure Mode and Effect Analysis) and QFD (Quality Function deployment) methods. This method is generally often used to identify the problem (risk) in the supply chain (supply chain). The advantages of this method lies in the framework for the planning of proactive strategies to mitigate risks that arise and create a healthy supply chain [1]. In the HOR method a risk agent (risk agent) is chosen that has the highest probability of occurrence and a severe risk event. Then mitigation measures are arranged that can reduce risk agents with the highest priority. By using the House of Risk (HOR) method, it is expected to get the results of risk analysis and mitigation actions that are more appropriate on the Balikpapan Samarinda Toll Road Development.

\section{A. Previous Research}

Risk is an event that may occur (uncertaint) having negative or positive effect on the project objectives. The definition of risk is explained by Sirait (2016) is the likelihood of events that can be detrimental to the company. While risk management has the sense of a logical and systematic method of identifying, analyzing, addressing and 
The $1^{\text {st }}$ International Conference on Business and Engineering Management (IConBEM 2020)

Table 1.

House of Risk Fase 1

\begin{tabular}{|c|c|c|c|c|c|c|c|c|c|}
\hline \multirow[b]{2}{*}{ Business Processes } & \multicolumn{8}{|c|}{ Risk Agents (Aj) } & \multirow[b]{2}{*}{$\begin{array}{l}\text { Severity of Risk } \\
\text { Event i (Si) }\end{array}$} \\
\hline & $\begin{array}{l}\text { Risk Event } \\
\text { (Ei) }\end{array}$ & $\mathrm{A} 1$ & A2 & $\mathrm{A} 3$ & A4 & A5 & A6 & A7 & \\
\hline \multirow{2}{*}{ Plan } & E1 & R11 & R12 & $\mathrm{R} 13$ & $\ldots$ & $\ldots$ & $\ldots$ & $\ldots$ & $\mathrm{S} 1$ \\
\hline & E2 & R21 & R22 & $\ldots$ & $\ldots$ & $\ldots$ & $\ldots$ & $\ldots$ & S2 \\
\hline \multirow{2}{*}{ Source } & E3 & R31 & $\ldots$ & $\ldots$ & $\ldots$ & $\ldots$ & $\ldots$ & $\ldots$ & S3 \\
\hline & E4 & R41 & $\ldots$ & $\ldots$ & $\ldots$ & $\ldots$ & $\ldots$ & $\ldots$ & S4 \\
\hline \multirow{2}{*}{ Make } & E5 & $\ldots$ & $\ldots$ & $\ldots$ & $\ldots$ & & $\ldots$ & $\ldots$ & S5 \\
\hline & E6 & $\ldots$ & $\ldots$ & $\ldots$ & $\ldots$ & $\ldots$ & $\ldots$ & $\ldots$ & S6 \\
\hline \multirow{2}{*}{ Deliver } & E7 & $\ldots$ & $\ldots$ & $\ldots$ & $\ldots$ & $\ldots$ & $\ldots$ & $\ldots$ & S7 \\
\hline & E8 & $\ldots$ & $\ldots$ & $\ldots$ & $\ldots$ & $\ldots$ & $\ldots$ & $\ldots$ & S8 \\
\hline Return & E9 & $\ldots$ & $\ldots$ & $\ldots$ & $\ldots$ & $\ldots$ & $\ldots$ & Rij & S9 \\
\hline \multicolumn{2}{|l|}{ Occurrence of Agent $\mathrm{j}$} & $\mathrm{O} 1$ & $\mathrm{O} 2$ & $\mathrm{O} 3$ & $\mathrm{O} 4$ & O5 & O6 & O7 & \\
\hline \multicolumn{2}{|c|}{ Agggregate Risk Potential j } & ARP1 & ARP2 & ARP3 & ARP4 & ARP5 & ARP6 & ARP7 & \\
\hline \multicolumn{10}{|c|}{ Priority Rank of Agent $j$} \\
\hline
\end{tabular}

Table 2.

House of Risk Fase 2

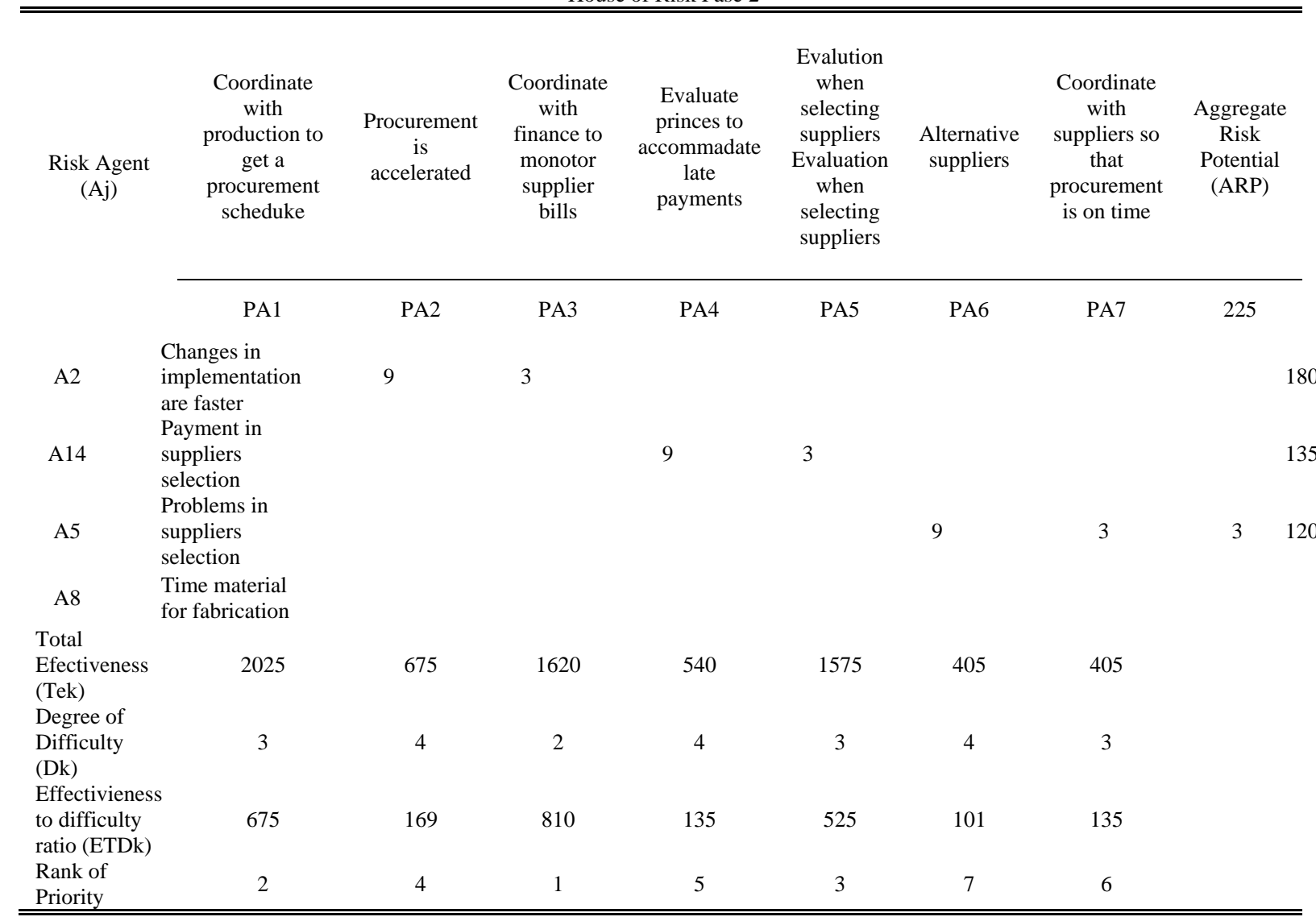

monitoring the risks involved in each activity or process. Risk management is a methodology that helps a manager make the best available resources.The purpose of risk management is to identify project risks and develop strategies that can significantly reduce risk or take action to avoid risk.

\section{B. House of Risk}

House of Risk or HOR is the development of the Failure
Modes and Effect Analysis (FMEA) method and the Quality Function Deployment (QFD) model in which the aim is to mdetermine the priority of the selected risk sources to take the most effective actions in order to reduce risks and sources of risk. By reducing the causes of risk, usually will prevent some of the risk event occurring. House of Risk is a method based on the need for risk management that focuses on preventive actions to determine the cause of risk which is a top priority then the appropriate mitigation measures are 
The $1^{\text {st }}$ International Conference on Business and Engineering Management (IConBEM 2020)

February $1^{\text {st }} 2020$, Institut Teknologi Sepuluh Nopember, Surabaya, Indonesia

Table 3.

Severity of Risk Event

\begin{tabular}{lclc}
\hline \hline \multirow{4}{*}{ Process } & Code & \multicolumn{1}{c}{ Risk Event } & Severity \\
\hline \multirow{4}{*}{ Order } & E1 & Technical evaluation & 4 \\
& E2 & Accelerate material & 5 \\
& E3 & the supplier cannot & 4 \\
& E4 & Increase in material & 4 \\
& E5 & Material volume & 4 \\
Procurement & E6 & Delay of negotiations & 5 \\
& E7 & Dependence on a & 5 \\
& E9 & The material & 5 \\
Deliver & E10 & Lack of raw material testing has & 4 \\
& E11 & Expedition cannot & 4 \\
Hand Over & E12 & Material damaged / & 4 \\
& E14 & Material damaged / & 4 \\
\hline \hline
\end{tabular}

Table 4.

Occurencey of Risk Agent

\begin{tabular}{cll}
\hline Code & \multicolumn{1}{c}{ Risk Agent } & Occurence \\
\hline A1 & Technical specifications are not & 3 \\
A2 & The implementation schedule is & 5 \\
A3 & Procurement approval takes a long & 4 \\
A4 & Increase in material prices & 4 \\
A5 & Problems in supplier selection & 4 \\
A6 & Price disagreement / delivery & 4 \\
A7 & Scarcity of raw materials & 3 \\
A8 & Material takes time to fabricate & 3 \\
A9 & Material shipped from abroad & 2 \\
A10 & Poor Expedition Performance & 3 \\
A11 & There was a natural disaster & 2 \\
A12 & Material delivery document issues & 2 \\
A13 & Unloading is not properly & 4 \\
A14 & Bill payments require a long period & 4 \\
\hline \hline
\end{tabular}

Table 5.

House of Risk Fase 1

\begin{tabular}{|c|c|c|c|c|c|c|c|c|c|c|c|c|c|c|c|c|c|}
\hline \multirow{2}{*}{ Scope } & \multirow{2}{*}{$\begin{array}{c}\text { Risk } \\
\text { Event } \\
\text { (Ei) }\end{array}$} & \multicolumn{15}{|c|}{ Risk Agent (Aj) } & \multirow{2}{*}{$\begin{array}{l}\text { Severity } \\
\text { of Risk } \\
\text { Event i }\end{array}$} \\
\hline & & A1 & A2 & A3 & A4 & A5 & A6 & A7 & A8 & A9 & A10 & A11 & A12 & A13 & A14 & A15 & \\
\hline \multirow{8}{*}{ Pemesanan } & E1 & 3 & & & & & & & & & & & & & & & 4 \\
\hline & E2 & & 9 & & & & & & & & & & & & & & 5 \\
\hline & E3 & & & & & 9 & & & & & 3 & & & & & 1 & 4 \\
\hline & E4 & & & & 3 & & & & & & & 1 & & & & & 4 \\
\hline & E5 & 1 & & & & & & & & & & & & & & & 4 \\
\hline & E6 & & & 3 & & & 3 & & & & & & & & & & 5 \\
\hline & E7 & & & & & & & 1 & & & & & & & & & 5 \\
\hline & E8 & & & & & & & 3 & 9 & 3 & & & & & & & 5 \\
\hline \multirow[t]{2}{*}{ Pengadaan } & E9 & 3 & & & & & & & & & & & & & & & 4 \\
\hline & E10 & & & & & & 3 & & & & & 1 & & & & & 5 \\
\hline \multirow[t]{2}{*}{ Pengiriman } & E11 & & & & & & & & & & 3 & & 3 & & & & 4 \\
\hline & E12 & & & & & & & & & & 3 & & & & & & 4 \\
\hline \multirow{2}{*}{ Serah Terima } & E13 & & & & & & & & & & & & & 3 & & & 5 \\
\hline & E14 & & & & & & & & & & & & & & 9 & & 5 \\
\hline \multicolumn{2}{|c|}{$\begin{array}{l}\text { Occurrence of Agent j } \\
\text { Aggragate Risk Potential }\end{array}$} & 3 & 5 & 4 & 4 & 4 & 4 & 3 & 3 & 2 & 3 & 2 & 2 & 4 & 4 & 2 & \\
\hline \multirow{2}{*}{\multicolumn{2}{|c|}{$\begin{array}{l}\text { j } \\
\text { Priority Rank } \\
\text { of Agent j }\end{array}$}} & 84 & 225 & 60 & 48 & 144 & 120 & 60 & 135 & 30 & 108 & 18 & 24 & 60 & 180 & 8 & \\
\hline & & 7 & 1 & 8 & 11 & 3 & 5 & 9 & 4 & 12 & 6 & 14 & 13 & 10 & 2 & 15 & \\
\hline
\end{tabular}

determined [2]. In the calculation of House of Risk calculation of the value of the RPN (Risk Potential Number) is obtained from sources of risk probability and impact damage when the risk occurs. Ranking from each risk source or called Aggregate Risk Potential (ARP) is used to determine the priority of preventive actions taken. Pujawan \& Geraldin (2009) adapted the HOQ (House of Quality) model to determine which risk is prioritized for precautionary measures first. If there are many sources of risk, then the project can determine which have a great potential to cause risk. Based on the HOQ standard, two
HOR models are proposed inTable 1 and Table 2; (1)HOR Phase 1 to determine the source of risk is a top priority for preventive measures; (2)HOR phase 2 is for priority mitigation actions by considering the most efficient mitigationcosts.

\section{1) House of Risk Phase 1}

HOR Phase 1 is the identification of risks that may occur during the project implementation period. This phase begins with the mapping of each kind of stage work. HOR 1 focuses on ranking the ARP which consists of 3 main factors namely the possible causes of the risk that occur and 
The $1^{\text {st }}$ International Conference on Business and Engineering Management (IConBEM 2020)

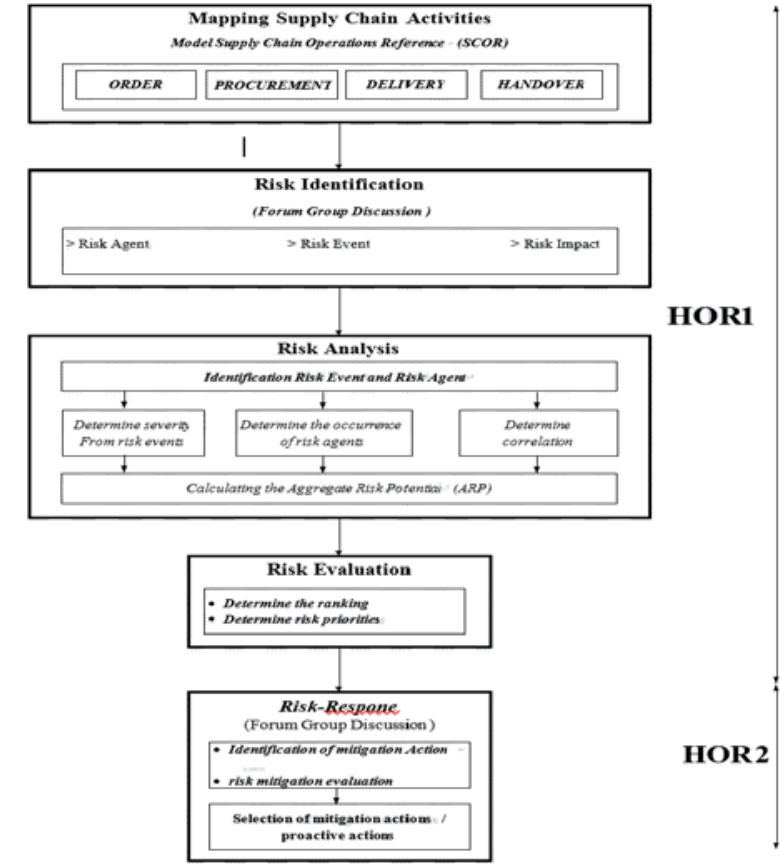

Figure 1. Mapping Supply Chain Activities.

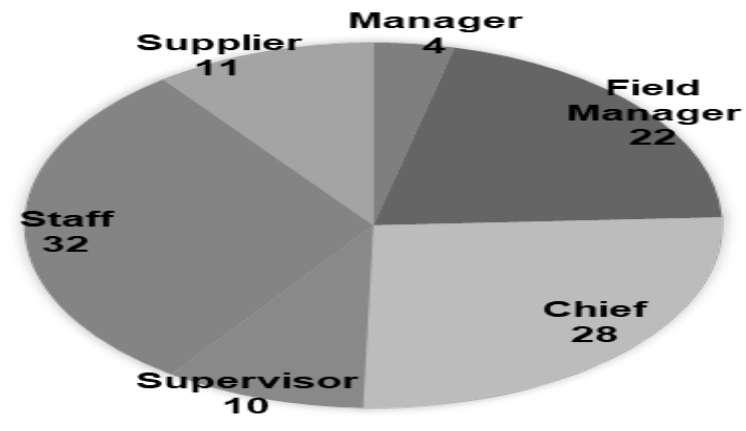

Figure 2. Research Respondents.

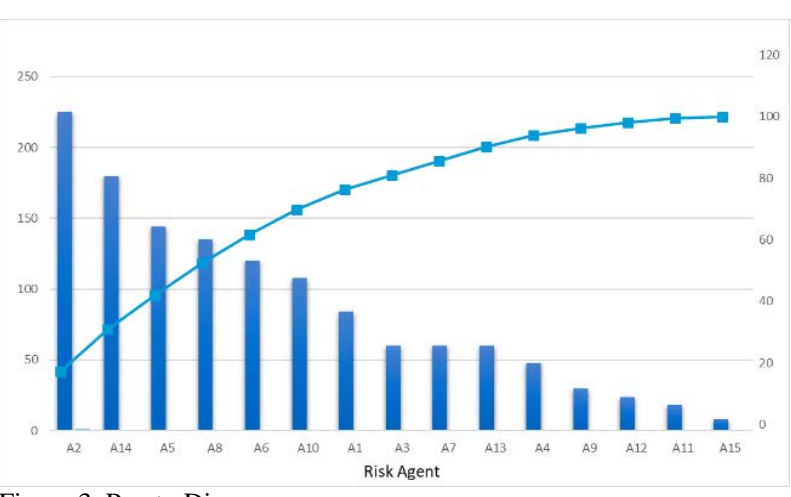

Figure 3. Pareto Diagram.

results in failure (Occurrence), the magnitude of the impact that may occur (Severity), and Interrelationship or in other words this phase focuses on the process of identifying risks include risk agents and risk events. This phase consists of the following

steps;(1)Identification of the stages of work aimed at knowing where there are sources of risk. This is usually done by mapping supply chain processes such as Plan, Source, deliver, Make dan Return (Model Supply Chain Operations Reference);(2)Measurement of the severity or impact that can be caused if the risk occurs in the project under study. Where can be given a scale rating of 1-10 regarding the severity (Si); (3)Identification of the causes of risk Aj (Risk Agents) and measurement of the opportunity value of theoccurrence of risk Oj (Occurance) a cause of risk. This Occurance states the level of opportunity for risk events that can interfere with the project. Identify risk agents by providing a scale of 1-10; (4)Compilation of the matrix that connects the relationship between the risk agent and the risk event shown in the correlation value (Rij).; (5)Perform ARP calculations to determine the level of events of the risk agent $(j)$ and the impact caused by a risk event triggered by the risk agent.; (6)Ranking of risk agents based on ARP values $\mathrm{ARP}=\mathrm{O} \sum \mathrm{S}$.Ri.

$$
\begin{array}{ll}
\text { Where : } & \mathrm{ARP}=\text { Aggregate Risk Potential } \\
\mathrm{O}=\text { Occurance } \\
\mathrm{S}=\text { Severity } \\
\mathrm{Ri}=\text { Nilai Korelasi }
\end{array}
$$

(7)Rating a risk agent based on the potential risk from the largest value to the smallest value.

\section{2) House of Risk Phase 2}

HOR phase 2 has the following steps: (1)Choosing a risk agent with the highest priority level based on the output of HOR phase 1; (2) Identify relevant actions to mitigate risks; (3)Determine the relationship between each preventive action on each risk trigger (risk agent) by using the values 0 , 1,3 , or 9 . Where these numbers indicate a relationship that is respectively, no, low, moderate and a strong relationship between actions (k) with agent (j); (4)Calculate the Total Effectiveness (Tech) of each action as follows :

Tek $=\sum$ ARPj $\mathrm{x}$ Ejk

$$
\begin{aligned}
\text { Where }: \text { Tek } & =\text { Efektifitas Total } \\
\text { ARPj } & =\text { Agregat Risk Potensial agen } \mathrm{j} \\
\text { Ejk } & =\text { Agen risiko } \mathrm{j}
\end{aligned}
$$

(5)Provide an assessment of the level of difficulty by representing each mitigation (Difficulty $D k$ ).

\section{II.METHOD}

The purpose of this study is to determine the risk mitigation measures for the material procurement process undertaken by the Balikpapan Samarinda Toll Road project using the House of Risk (HOR) method. Previously, a risk analysis had been carried out qualitatively, that is, analyzing risks based on the impact and probability of the risk event to be followed up in accordance with the priority scale. From the literature study that has been done, to analyze risk management in the supply chain system, the House of Risk (HOR) method is used. With this method, it is expected that risk identification and mitigation actions taken can precisely minimize risks from procurement of Balikpapan Samarinda Toll Road project material.This description of the Samarinda Samarinda Toll Road Project can be used as a basis for identifying risk agents and risk events. The steps of this research can be seen in the following figure1. 
The $1^{\text {st }}$ International Conference on Business and Engineering Management (IConBEM 2020)

February $1^{\text {st }} 2020$, Institut Teknologi Sepuluh Nopember, Surabaya, Indonesia

\begin{tabular}{|c|c|c|c|c|c|c|c|c|c|}
\hline \multirow{3}{*}{\multicolumn{2}{|c|}{ Risk Agent (Aj) }} & \multicolumn{7}{|c|}{ Preventive Action (Pak) } & \multirow{3}{*}{$\begin{array}{c}\text { Aggregate } \\
\text { Risk Potential } \\
\text { (ARP) }\end{array}$} \\
\hline & & \multirow{2}{*}{\begin{tabular}{|c|}
$\begin{array}{c}\text { Coordinate } \\
\text { with } \\
\text { production to } \\
\text { get a } \\
\text { procurement } \\
\text { schedule }\end{array}$ \\
PA1 \\
\end{tabular}} & \multirow{2}{*}{\begin{tabular}{|c|}
$\begin{array}{c}\text { Procurement is } \\
\text { accelerated }\end{array}$ \\
PA2
\end{tabular}} & \multirow{2}{*}{$\begin{array}{c}\begin{array}{c}\text { Coordinate } \\
\text { with finance to } \\
\text { monitor } \\
\text { supplier bills }\end{array} \\
\text { PA3 } \\
\end{array}$} & \multirow{2}{*}{\begin{tabular}{|c|}
$\begin{array}{c}\text { Evaluate prices } \\
\text { to } \\
\text { accommodate } \\
\text { late payments }\end{array}$ \\
PA4 \\
\end{tabular}} & \multirow{2}{*}{\begin{tabular}{|c|} 
Evaluation \\
when selecting \\
suppliers \\
Evaluation \\
when selecting \\
suppliers \\
PA5
\end{tabular}} & \multirow{2}{*}{$\begin{array}{c}\begin{array}{c}\text { Alternative } \\
\text { supplier }\end{array} \\
\text { PA6 }\end{array}$} & \multirow{2}{*}{$\begin{array}{c}\text { Coordinate } \\
\text { with suppliers } \\
\text { so that } \\
\text { procurement is } \\
\text { on time }\end{array}$} & \\
\hline & & & & & & & & & \\
\hline A2 & $\begin{array}{l}\text { Changes in implementation are } \\
\text { faster }\end{array}$ & 9 & 3 & & & & & & 225 \\
\hline A14 & Payment $\mathrm{n}$ requires a long time & & & 9 & 3 & & & & 180 \\
\hline A5 & Problems in supplier selection & & & & & 9 & 3 & 3 & 135 \\
\hline A8 & Time material for fabrication & & & & & 3 & & & 120 \\
\hline Tota & Efectiveness (Tek) & 2025 & 675 & 1620 & 540 & 1575 & 405 & 405 & \\
\hline Degr & ee of Difficully (Dk) & 3 & 4 & 2 & 4 & 3 & 4 & 3 & \\
\hline Effec & tiveness to difficulty ratio (ETDk) & 675 & 169 & 810 & 135 & 525 & 101 & 135 & \\
\hline Rank & of Priority & 2 & 4 & 1 & 5 & 3 & 7 & 6 & \\
\hline
\end{tabular}

Figure 4. House of Risk Fase 2.

\section{RESULT AND DISCUSSION}

\section{A. Data Analysis}

Selected respondents are managers, employees and suppliers who work on the Balikpapan Samarinda Toll Road Project. Recap respondent data that aims to get an idea of the background of the respondents. Respondent data can be seen in Figure 2.

\section{B. Risk Identification}

The identification of risk events in the procurement of Balikpapan Samarinda toll road projects was carried out through literature studies and brainstorming with project management in which 14 risk events occurred in the material procurement process.

\section{Risk Analysis}

Then, the identified risk events are measured for severity scale (risk impact) through filling in the questionnaire conducted on the respondent. Severity scale assessment (risk impact) 1 - 5 on the risk event (risk event). The following severity scale assessment results obtained from the respondents related, can see table 3 .

Risk agent identification is the identification of the triggering factors for the occurrence of risk events so that by implementing a mitigation strategy to the risk trigger can reduce the risk events that will occur. Based on the results of brainstorming, a total of 15 risk triggers in the material procurement process were obtained. The next step, similar to the risk event, each risk agent is also measured by the scale of occurrence using a questionnaire against respondents. Assessment of occurrence scale 1 - 5 on risk agents. Occurencey of risk agent can be see table 4 .

\section{D.Risk Evaluation}

The next step is to calculate the Aggregate Risk Potential (ARP) obtained from the multiplication of the probability of the risk source and the impact related to that risk. After correlating and calculating the Aggregate Risk Potential (ARP), the final step is to create a House of Risk phase 1 in table by combining risk events, risk agents, correlations and the results of Aggregate Risk Potential (ARP) calculations into a table 5 .

\section{E. Risk Respons}

In HOR phase 2, a risk prevention agent is prepared in which the results of the HOR phase 1 are used. Based on the results of the Pareto diagram application, obtained from the cumulative percentage of the total ARP, there is one priority risk agent, namely (A2) The implementation schedule is faster. However, based on brainstorming with project management that will become a priority risk agent for preventive action, namely 4 top-ranking risk. Because according to the management of the risk agent, it is considered to be able to hamper the smooth procurement of project materials. Selected risk agents will be included in the House of Risk phase 2 model to determine the level and priority of the mitigation actions to be taken by considering several factors that influence the level of ease of realization of the mitigation actions.Then the next stage, the total effectiveness of each preventive action (PA) will be calculated to be used as a calculation of the effectiveness ratio or ETD (Effectiveness to Difficulty Ratio) value of the implementation of preventive action. Where the value of the ratio is obtained from the division of the total effectiveness with the degree / level of difficulty in applying PA (preventive action). The measurement of the effectiveness ratio or the value of ETD (Effectiveness to Difficulty Ratio) aims to find out the ranking of each preventive action variable that can be done in advance according to the level of simplicity and effectiveness in Figure 4.

\section{F. Implications}

Based on the results of calculations on the House of Risk phase 2 model, the results of the ranking of preventive actions taken first priority (PA 3) Coordinate with the finance department to monitor supplier bills. This preventive action can reduce the risk agent (A 14) Payment of bills requires a long period of time. In accordance with the financial procedures of PT Wijaya Karya for payment to suppliers using bank facilities where verification starts from project management, division management, department management to the finance department before payment is made. This requires time so that regular monitoring needs to be carried out regarding the status of these bills. From this monitoring it can be seen that the status of bills can be minimized late payment to suppliers. PA3 Preventive Action 
The $1^{\text {st }}$ International Conference on Business and Engineering Management (IConBEM 2020)

February $1^{\text {st }} 2020$, Institut Teknologi Sepuluh Nopember, Surabaya, Indonesia

is easy to implement because it only requires financial personnel to monitor bills.

The second preventive action is (PA1) Coordinate with the production department to get an accurate procurement schedule. Preventive action is easy to do because it can be done in the form of weekly or monthly meetings within the internal scope of the Balikpapan Samarinda Toll Road project. By knowing the work plan, it can know the material needs plan.

The third preventive action is (PA5) Conduct an evaluation when appointing a supplier. Preventive action is quite easy to do by implementing PT Wijaya's procedures regarding CSI (Customer Satisfaction Index). By evaluating supplier performance, it can be eliminated by suppliers who are less competent in the PT Wijaya Karya project.

\section{G.Conclusion}

The results of the identification of risk events in the procurement process of the Balikpapan Samarinda Toll Road project found 14 risk events. While the results of the identification of risk agents obtained 15 risk agents. The two variables are input for the House of Risk phase 1 model through the measurement of impact (severity) and the level of probability of occurrence obtained from the results of a questionnaire against 108 stakeholder respondents in the Balikpapan Samarinda Toll Road project to get the correlation value of each risk event. The results of the House of Risk phase 1 model are processed using pareto diagrams, it is found that the top risk agents have a significant influence up to $50 \%$ of material procurement risk events, namely:(A2)Implementation changes become faster, (A14)
Payments require a long tim (A5 ) Problems in supplier selection and (A8) Material takes time to fabricate. Pareto diagram can be seen in Figure 3.

\section{H.Recommendation}

Upon the research result, suggestions can be given as follow; (1)For the company, Managerial implications need to be done by project management that is monitoring supplier bills and updating periodically to find out the work payment process. Periodically also updating procurement schedules in accordance with project needs. The third is the implementation of procedures related to the assessment of PT Wijaya Karya subcon (VPI) to evaluate the performance of suppliers; (2)For futher research, The results of the House of Risk phase 2 found 6 preventive actions which then carried out the calculation of the value of ETD (Effectiveness to Difficulty Ratio) selected 3 highest priorities that were immediately followed up by the project team namely (PA3) Coordinate with finance to monitor supplier bills, (PA1) Coordinate with production to get an accurate procurement schedule and (PA5) Evaluation when selecting suppliers.

\section{REFERENCES}

[1] J. Teknologi, I. Pertanian, M. Ulfah, and M. Syamsul, "Analisis dan perbaikan manajemen risiko rantai pasok gula rafinasi dengan pendekatan house of risk," Anal. Dan Perbaikan Manaj. Risiko Rantai Pasok Gula Rafinasi Dengan Pendekatan House Risk, vol. 26, no. 1, pp. 87-103, 2016, doi: 10.24961/jtip.26.\%p.

[2] I. Pujawan and L. Geraldin, "House of risk: a model for proactive supply chain risk management,” Bussiness Process Manag. J., vol. 15, no. 2, pp. 963-967, 2009. 